\title{
Developing Seed-propagated Lowbush Blueberry Families
}

\author{
Andrew Raymond Jamieson ${ }^{1,2}$ \\ Agriculture and Agri-Food Canada, Atlantic Food and Horticulture \\ Research Centre, 32 Main Street, Kentville, Nova Scotia, B4N 1J5, Canada
}

Additional index words. Vaccinium angustifolium, breeding, rhizomes

\begin{abstract}
The benefits of lowbush blueberry seedlings over clonally propagated plants, in terms of improved plant performance and low cost per plant, led to the establishment of a trial of 42 seedling families in $\mathbf{1 9 9 0}$. The purpose of this trial was to identify hybrid seed that produces plants that are high yielding and of good fruit quality. Considering berry yield and quality, seedling families KBF-7, KBF-10, KBF-13, and KBF-42 were identified as top performers. All of these have 'Fundy' as one parent. KBF-7 is well suited to producing blueberries for marketing as high-quality fresh fruit. KBF-10 spreads well by rhizomes and may be suited as fill-in plants for bare areas in commercial lowbush blueberry fields.
\end{abstract}

The expansion of the highbush blueberry (principally Vaccinium corymbosum L.) industry worldwide is supported by several successful breeding programs that have created cultivars with improvements in fruit size and firmness while retaining a highly desirable fresh flavor. These cultivars are vegetatively propagated by hardwood or softwood cuttings or by micropropagation, all of which stably conserve the cultivar's genotype. In contrast, the extensive lowbush blueberry fields of Maine, Quebec, and the Atlantic Provinces of Canada are colonized by a diversity of genotypes, mostly $V$. angustifolium Aiton. These lowbush blueberry fields were developed from forest or old fields, which naturally contained blueberry plants. These plants spread by rhizomes to form colonies often several meters in diameter, but originally they would have arrived as seed dispersed in the droppings of birds or mammals (Hall et al., 1979). The genetic diversity within a field is readily visible by color variation observed when shoots are young, during flowering, and especially in the fall when the leaves are developing different shades of red. Heterogeneity can also be observed at harvest time, expressed as variability in berry yield, size, and color, which is related to the amount of waxy bloom on the fruit. This heterogeneity has been verified by molecular techniques (Burgher et al., 2002; Burgher-MacLellan and MacKenzie, 2004).

Received for publication 13 Dec. 2007. Accepted for publication 15 May 2008.

Atlantic Food and Horticulture Research Centre Contribution no. 2348.

I thank Avard Brydon for the initial technical responsibilities followed by Pansy Rand and Michael Graves and Dr. Ken McRae, Sherry Fillmore, and Brad Walker for statistical design and analysis. I thank Dr. John DeLong and Dr. Nancy Nickerson for reviewing the manuscript.

${ }^{1}$ Fruit Breeder.

${ }^{2}$ To whom reprint requests should be addressed; e-mail jamiesona@agr.gc.ca
The variability in fruit yield is especially important because unlike a uniformly highyielding highbush blueberry field made up of two or three genotypes, a lowbush blueberry field includes many low-yielding genotypes. Eaton (1954) examined the variability in yield in a lowbush blueberry field in New Brunswick over a 5-year period. Recording yield in rod-square plots $\left(25 \mathrm{~m}^{2}\right)$, production averaged $1600 \mathrm{~kg} \cdot \mathrm{ha}^{-1}$ with a range of 40 to $12,000 \mathrm{~kg} \cdot \mathrm{ha}^{-1}$. Eaton (1954) stated that this extreme lack of uniformity could be explained by plant genetics, soil characteristics, and weed prevalence. The genetic component of variability in yield was measured by Hepler and Yarborough (1991) by examining the fruit yield of 100 randomly selected lowbush blueberry clones, which were transplanted into more uniform soil and then watered, fertilized, and weeded. Yields were normally distributed with a range of 400 to $17,000 \mathrm{~kg} \cdot \mathrm{ha}^{-1}$ with a mean of $7726 \mathrm{~kg} \cdot \mathrm{ha}^{-1}$. A field-scale yield of $4000 \mathrm{~kg} \cdot \mathrm{ha}^{-1}$, a figure well below the potential of a high-yielding genotype, would be considered very good by commercial growers. The idea, therefore, of selecting the most productive genotypes, propagating them, and establishing highly productive fields or improving nonproductive fields is meritorious (Brierley and Kenety, 1920; Johnston, 1935; Kender, 1965).

Blueberry plants spread slowly. Fields in production for 50 years or more may have nearly $100 \%$ cover, but young fields may have less than 50\% (Smagula and Yarborough, 1990). Filling in those bare spots with improved genotypes is one way to improve productivity. Efforts to domesticate the lowbush blueberry through clonal selection and breeding have resulted in the introduction of several cultivars between 1975 and 1987 (Hall et al., 1988). Although these cultivars have been useful for physiological research, and a few fresh market plantings have been established, they have never been accepted as a method of expanding existing commercial blueberry fields (Wood, 2004). One reason for this is that plants propagated by cuttings tend to produce few rhizomes unless careful attention is paid to initial plant quality, fertility, and water requirements (Kender, 1966, 1967; Smagula and Yarborough, 1990). In contrast, plants grown from seeds produce rhizomes more freely (Aalders et al., 1972; Kender, 1967), but variation in fruit characteristics is problematic and fruit yields are often $50 \%$ lower than those of the parental

Table 1. Parental genotypes, their origin, number of crosses, and main attributes.

\begin{tabular}{|c|c|c|c|}
\hline Genotypes & Origin or pedigree & $\begin{array}{c}\text { Number of } \\
\text { crosses }\end{array}$ & Outstanding attributes \\
\hline Augusta & 3302 o- $\mathrm{p}^{\mathrm{z}}$ from Maine & 2 & Yield, size, color \\
\hline Blomidon & $451 \times$ Augusta & 2 & Yield, size, color \\
\hline Brunswick & Native NB selection & 11 & Size, flavor \\
\hline Cumberland & Native NS selection & 3 & Flavor \\
\hline Fundy & Augusta o-p & 14 & Yield, size, color, firmness \\
\hline 416 & Native NS selection & 2 & Firmness, rhizomes \\
\hline 451 & Native NS selection & 1 & Yield \\
\hline 537 & Native NS selection & 1 & Yield, size, flavor \\
\hline 607 & Native NS selection & 3 & Yield, color, lateness \\
\hline 633 & Native NS selection & 3 & Yield, lateness \\
\hline 674 & Native NS selection & 2 & Yield, color, flavor \\
\hline 686 & Native NS selection & 1 & Color \\
\hline 701 & Native NS selection & 3 & Lateness \\
\hline $70-21$ & Augusta $\times$ Chignecto & 1 & Color \\
\hline $70-27$ & Augusta $\times 340$ & 2 & Size, color \\
\hline $72-3$ & Unknown & 7 & Yield, size, color \\
\hline $73-9$ & $680 \times 622$ & 3 & Yield, firmness \\
\hline $73-14$ & $682 \times 760$ & 1 & Yield, size, flavor, color \\
\hline $73-17$ & $682 \times 794$ & 1 & Color \\
\hline $73-22$ & $680 \times 662$ & 2 & Flavor, color \\
\hline $73-23$ & $679 \times 694$ & 1 & Color \\
\hline $77-10$ & $73-31 \times 73-17$ & 5 & Size, flavor \\
\hline $78-22$ & $678 \times$ Brunswick & 2 & Size \\
\hline $79-12$ & Cumberland $\times 325$ & 7 & Flavor, rhizomes \\
\hline $80-05$ & $674 \times$ Brunswick & 1 & Firmness \\
\hline $80-07$ & $686 \times$ Brunswick & 1 & Firmness \\
\hline $83-05$ & Me4161 × 72-3 & 1 & Color, firmness \\
\hline
\end{tabular}

${ }^{\mathrm{z}}$ Open-pollinated. 
clones (Aalders et al., 1979; Jamieson and Nickerson, 2003). Hall (1983) reported that seedlings from controlled crosses between the better genotypes produced an average yield of $7.4 \mathrm{t} \cdot \mathrm{ha}^{-1}$ and berry weight of 580 mg compared with $4.4 \mathrm{t} \cdot \mathrm{ha}^{-1}$ and $380 \mathrm{mg}$ for open-pollinated seedlings from wild unselected blueberries. The potential advantages of a seed-propagated family-lower cost planting stock, more rapid plant establishment, and the ability to store seed and germinate when required-have stimulated this research to identify a hybrid population combining high fruit quality and productivity with a natural tendency to produce rhizomes.

\section{Materials and Methods}

Selection of parents. The breeding program begun in 1961 (Hall, 1983) continued into the 1980s with many genotypes being selected and established in performance trials. These trials provided data on fruit size and yield. Observations were also made on fruit color (density of the waxy bloom), firmness, flavor, and season of harvest. These phenotypic characteristics were used to select the parents used in this study (Table 1). Genotype 451 was included because it was shown by Aalders and Hall (1975) to produce high-yielding seedlings when crossed with 'Augusta'. In addition, breeding records were examined to identify which genotypes tended to be better parents, i.e., those parents most often present in the pedigrees of advanced selections or those that gave rise to more selections.

Crossing. Parental plants were dug from field plots after leaf fall, potted, and placed in cold storage at $2{ }^{\circ} \mathrm{C}$ in Nov. 1988 . They were moved into a heated greenhouse in Feb. 1989 to promote flowering. Crosses were made on unemasculated flowers because $V$. angustifolium is largely self-sterile (Hall et al., 1979) and it is unlikely that emasculation would be economical in a commercial seed production scheme. Seeds were extracted from fruit in Spring 1989, germinated, and grown in the greenhouse and subsequently in a coldframe to prepare them for cold storage over Winter 1990. Plants were established in a field plot in Spring 1990 at Sheffield Mills, Kings County, Nova Scotia, Canada in a sandy loam soil of the Somerset series, an orthic humo-ferric podsol, with $2.7 \%$ organic matter and $\mathrm{pH} 5.4$.

Plot design. Plants of 42 crosses [Kentville Blueberry Families (KBFs)] were arranged in a randomized complete block design with six blocks, 252 plots in total. In each block, a cross was represented by an eight-plant row, its position randomized within the block, which contained six columns and seven rows. Plants were set at $50-\mathrm{cm}$ spacings in row with $125 \mathrm{~cm}$ between rows. Plots were harvested with blueberry rakes supplemented with hand picking. The first harvest was in 1992 followed by burn-pruning in early Spring 1993. Similarly, all plots were harvested in 1994, pruned in 1995, mulched with aged hardwood chips, and harvested in 1996. One half of the plots (blocks 4, 5, and 6) were pruned in Spring 1997 and harvested in 1998. Blocks 1, 2 , and 3 were harvested in 1997 (a second successive crop), pruned in 1998, and harvested in 1999. Blocks 4, 5, and 6 were pruned in 1999 and harvested in 2000. In 1999 and 2000 , only plots of the better families were harvested. In 1995 and subsequent years, pruning was by mowing rather than by burning. In 1994, the plots were evaluated for uniformity by counting the number of plants that were atypical of the family and a rating was done on the degree of spreading (rhizome production). At the 1994 harvest, berries were scored 1 to 5 (best) for their waxy bloom (a high score indicates a lighter blue color), overall appearance of a tray of harvested fruit, firmness, and flavor. Firmness was rated by manually squeezing several berries individually until splitting and comparing with 'Fundy', which is considered firmness rating
4. Flavor was rated by tasting a sample of 10 to 15 berries collectively. Statistical analysis was by Genstat 8.2 (Payne, 2000).

\section{Results and Discussion}

The mean yield for all $42 \mathrm{KBFs}$ increased from $1193 \mathrm{~g} /$ plot in 1992 to $3120 \mathrm{~g}$ in 1998 (Table 2). The yield in 1996 was not greater than the previous crop, which may have resulted from the mulch application. Other major variables that affect lowbush blueberry yield include abundance of pollinating insects during flowering and moisture availability during fruit maturation (Yarborough, 2004). The yield in 1997 was low because it was a second consecutive crop, which has been shown to be $\approx 70 \%$ of a first crop in unselected managed fields (Jordan and Eaton, 1995). The highest yield was recorded in 1998 for KBF 7 at $5577 \mathrm{~g} / \mathrm{plot}\left(11 \mathrm{t} \cdot \mathrm{ha}^{-1}\right)$.

Table 2. Fruit yields of 42 Kentville blueberry families (KBFs).

\begin{tabular}{|c|c|c|c|c|c|c|c|}
\hline \multirow{2}{*}{$\mathrm{KBF}$} & \multirow[b]{2}{*}{ Cross } & \multicolumn{6}{|c|}{ Fruit yield per plot (g) } \\
\hline & & 1992 & 1994 & 1996 & $1997^{z}$ & $1998^{z}$ & 1992 to $1998^{y}$ \\
\hline 1 & Augusta $\times 451$ & 1,144 & 2,236 & 1,690 & 1,008 & 2,595 & 1,785 \\
\hline 2 & Augusta $\times$ Brun. & 1,421 & 2,379 & 1,893 & 2,011 & 3,259 & 2,097 \\
\hline 3 & Blomidon $\times$ Brun. & 1,158 & 2,246 & 1,942 & 861 & 2,681 & 1,893 \\
\hline 4 & Blomidon $\times 72-3$ & 1,362 & 2,505 & 1,860 & 628 & 1,737 & 1,950 \\
\hline 5 & Cumber. $\times$ Brun . & 1,120 & 2,543 & 2,673 & 1,252 & 3,849 & 2,329 \\
\hline 6 & Cumber. $\times 77-10$ & 458 & 1,580 & 1,887 & 1,096 & 3,005 & 1,528 \\
\hline 7 & Fundy $\times$ Brun & 1,301 & 3,419 & 3,691 & 1,805 & 5,577 & 2,658 \\
\hline 8 & Fundy $\times$ Cumber. & 886 & 2,195 & 2,513 & 1,298 & 3,659 & 2,095 \\
\hline 9 & Fundy $\times 537$ & 1,364 & 3,046 & 3,524 & - & - & - \\
\hline 10 & Fundy $\times 416$ & 1,350 & 2,943 & 2,979 & 1,449 & 3,257 & 2,989 \\
\hline 11 & Fundy $\times 674$ & 1,794 & 2,917 & 3,054 & 969 & 3,787 & 2,723 \\
\hline 12 & Fundy $\times 70-27$ & 953 & 2,253 & 2,014 & 1,432 & 2,675 & 1,875 \\
\hline 13 & Fundy $\times 72-3$ & 2,029 & 3,456 & 3,340 & 1,564 & 4,485 & 3,100 \\
\hline 14 & Fundy $\times 73-9$ & 1,667 & 2,527 & 1,803 & 969 & 2,853 & 2,085 \\
\hline 15 & Fundy $\times 73-14$ & 1,260 & 2,420 & 2,121 & 1,722 & 2,463 & 2,038 \\
\hline 16 & Fundy $\times 73-22$ & 1,084 & 1,735 & 2,118 & 661 & 2,563 & 1,781 \\
\hline 17 & $633 \times 607$ & 1,061 & 3,294 & 3,749 & 875 & 4,782 & 2,942 \\
\hline 18 & $674 \times$ Brun. & 1,595 & 2,719 & 2,929 & 1,328 & 4,307 & 2,633 \\
\hline 19 & $686 \times$ Brun. & 1,032 & 1,852 & 1,928 & 959 & 2,706 & 1,766 \\
\hline 20 & $701 \times 607$ & 891 & 2,737 & 3,094 & 1,192 & 3,768 & 2,419 \\
\hline 21 & $701 \times 633$ & 1,114 & 2,882 & 2,916 & 836 & 3,939 & 2,407 \\
\hline 22 & $70-21 \times$ Brun. & 1,549 & 2,196 & 1,861 & 1,438 & 2,687 & 1,969 \\
\hline 23 & 70-27 × Brun & 1,230 & 1,960 & 1,894 & 1,814 & 2,756 & 1,830 \\
\hline 24 & 72-3 × Brun & 1,574 & 2,650 & 2,731 & 1,902 & 3,009 & 2,427 \\
\hline 25 & $73-2 \times 607$ & 1,044 & 3,150 & 2,906 & 1,136 & 3,593 & 2,536 \\
\hline 26 & $72-3 \times 633$ & 1,513 & 3,404 & 3,907 & 791 & 4,846 & 3,135 \\
\hline 27 & $72-3 \times 701$ & 1,011 & 3,442 & 3,687 & 1,445 & 3,379 & 3,250 \\
\hline 28 & $72-3 \times 79-12$ & 1,172 & 3,154 & 2,398 & 1,376 & 3,459 & 2,434 \\
\hline 29 & $73-9 \times 73-14$ & 1,276 & 2,068 & 1,508 & 445 & 2,843 & 1,725 \\
\hline 30 & $73-17 \times 73-23$ & 970 & 2,330 & 1,437 & 688 & 1,329 & 1,557 \\
\hline 31 & $73-22 \times 73-9$ & 403 & 1,299 & 1,399 & 205 & 1,733 & 1,131 \\
\hline 32 & 77-10 × Brun & 890 & 1,490 & 1,404 & 1,080 & 1,807 & 1,361 \\
\hline 33 & $77-10 \times$ Fundy & 1,428 & 1,979 & 1,583 & 1,225 & 2,503 & 1,807 \\
\hline 34 & $78-22 \times$ Fundy & 1,290 & 2,989 & 3,755 & 1,800 & 4,642 & 2,907 \\
\hline 35 & $78-22 \times 77-10$ & 1,406 & 2,183 & 2,038 & 1,226 & 2,619 & 2,028 \\
\hline 36 & $79-12 \times$ Fundy & 1,194 & 2,557 & 2,139 & 880 & 2,616 & 2,085 \\
\hline 37 & $79-12 \times$ Brun. & 1,171 & 2,513 & 2,021 & 2,108 & 2,363 & 2,021 \\
\hline 38 & $79-12 \times 416$ & 1,160 & 3,094 & 2,489 & 780 & 2,685 & 2,291 \\
\hline 39 & $79-12 \times 77-10$ & 720 & 3,028 & 2,099 & 670 & 3,306 & 2,137 \\
\hline 40 & $79-12 \times 80-05$ & 868 & 2,834 & 2,090 & 771 & 3,128 & 2,054 \\
\hline 41 & $79-12 \times 80-07$ & 1,022 & 2,860 & 2,479 & 1,209 & 3,190 & 2,270 \\
\hline 42 & 83-05 $\times$ Fundy & 1,205 & 2,790 & 2,763 & 1,213 & 2,263 & 2,240 \\
\hline ANO & -F probability & $<0.001$ & $<0.001$ & $<0.001$ & $<0.001$ & $<0.001$ & $<0.001$ \\
\hline $\operatorname{LSD}(1$ & $0.05)$ & 626 & 976 & 1,008 & 640 & 1509 & 704 \\
\hline Degr & of freedom & 200 & 201 & 201 & 82 & 82 & 197 \\
\hline Gran & lean of $42 \mathrm{KBFs}$ & 1,193 & 2,568 & 2,436 & 1,168 & 3,120 & 2202 \\
\hline
\end{tabular}

${ }^{2}$ Based on three blocks.

${ }^{\mathrm{y}}$ Mean of 1992, 1994, 1996, 1998 from analysis of variance taking block and year effects into consideration. 
Table 3. Berry weight of 42 Kentville blueberry families (KBFs).

\begin{tabular}{|c|c|c|c|c|c|c|c|}
\hline \multirow[b]{2}{*}{ KBF } & \multirow[b]{2}{*}{ Cross } & \multicolumn{6}{|c|}{ Wt of 50 berries $(\mathrm{g})$} \\
\hline & & 1992 & 1994 & 1996 & $1997^{z}$ & $1998^{z}$ & 1992 to $1998^{y}$ \\
\hline 1 & Augusta $\times 451$ & 26.7 & 22.2 & 30.2 & 25.7 & 23.5 & 25.7 \\
\hline 2 & Augusta $\times$ Brun & 30.7 & 26.2 & 31.2 & 26.6 & 25.8 & 28.9 \\
\hline 3 & Blomidon $\times$ Brun & 29.0 & 23.0 & 28.5 & 27.2 & 25.1 & 26.4 \\
\hline 4 & Blomidon $\times 72-3$ & 34.2 & 22.2 & 29.0 & 29.3 & 25.2 & 27.5 \\
\hline 5 & Cumber. $\times$ Brun. & 31.0 & 25.0 & 28.2 & 23.1 & 23.2 & 27.4 \\
\hline 6 & Cumber. $\times 77-10$ & 25.2 & 23.5 & 27.7 & 24.8 & 24.1 & 25.1 \\
\hline 7 & Fundy × Brun. & 34.5 & 23.8 & 33.7 & 27.9 & 27.6 & 30.4 \\
\hline 8 & Fundy $\times$ Cumber . & 27.8 & 20.5 & 29.8 & 24.4 & 22.8 & 25.5 \\
\hline 9 & Fundy $\times 537$ & 30.5 & 23.5 & 31.5 & - & - & - \\
\hline 10 & Fundy $\times 416$ & 28.2 & 21.2 & 25.2 & 26.2 & 23.6 & 24.3 \\
\hline 11 & Fundy $\times 674$ & 30.8 & 25.5 & 34.8 & 28.9 & 27.0 & 29.6 \\
\hline 12 & Fundy $\times 70-27$ & 29.5 & 22.3 & 32.3 & 28.9 & 26.8 & 27.9 \\
\hline 13 & Fundy $\times 72-3$ & 34.0 & 25.0 & 30.7 & 33.0 & 29.2 & 29.5 \\
\hline 14 & Fundy $\times 73-9$ & 26.2 & 21.8 & 28.3 & 27.1 & 23.9 & 24.9 \\
\hline 15 & Fundy $\times 73-14$ & 29.2 & 24.5 & 32.8 & 28.0 & 25.5 & 28.1 \\
\hline 16 & Fundy $\times 73-22$ & 28.7 & 22.5 & 28.5 & 27.6 & 26.0 & 26.3 \\
\hline 17 & $633 \times 607$ & 24.8 & 19.7 & 27.5 & 26.2 & 21.9 & 23.2 \\
\hline 18 & $674 \times$ Brun & 31.5 & 24.3 & 32.2 & 27.7 & 26.2 & 28.7 \\
\hline 19 & $686 \times$ Brun & 27.2 & 20.7 & 22.7 & 25.8 & 23.2 & 23.3 \\
\hline 20 & $701 \times 607$ & 21.0 & 17.0 & 23.2 & 20.3 & 19.3 & 20.1 \\
\hline 21 & $701 \times 633$ & 22.5 & 18.5 & 26.8 & 23.0 & 21.5 & 22.3 \\
\hline 22 & 70-21 × Brun. & 29.7 & 20.7 & 24.7 & 26.8 & 24.9 & 24.8 \\
\hline 23 & 70-27 × Brun. & 30.2 & 23.0 & 32.0 & 25.8 & 25.0 & 27.8 \\
\hline 24 & 72-3 × Brun. & 35.0 & 24.3 & 32.7 & 31.3 & 29.5 & 30.3 \\
\hline 25 & $73-2 \times 607$ & 27.5 & 18.7 & 24.3 & 22.9 & 22.0 & 23.2 \\
\hline 26 & $72-3 \times 633$ & 35.5 & 20.8 & 29.5 & 31.2 & 28.2 & 28.0 \\
\hline 27 & $72-3 \times 701$ & 28.7 & 22.5 & 28.8 & 25.8 & 22.2 & 25.8 \\
\hline 28 & $72-3 \times 79-12$ & 34.5 & 24.7 & 31.0 & 28.8 & 27.0 & 29.6 \\
\hline 29 & $73-9 \times 73-14$ & 28.3 & 23.0 & 28.8 & 26.2 & 22.6 & 25.9 \\
\hline 30 & $73-17 \times 73-23$ & 27.8 & 22.2 & 28.3 & 27.6 & 24.4 & 25.4 \\
\hline 31 & $73-22 \times 73-9$ & 23.3 & 21.2 & 23.3 & 23.3 & 21.2 & 22.3 \\
\hline 32 & 77-10 × Brun. & 29.7 & 22.2 & 29.3 & 26.5 & 24.8 & 26.8 \\
\hline 33 & $77-10 \times$ Fundy & 30.8 & 27.7 & 34.7 & 32.2 & 28.9 & 30.6 \\
\hline 34 & $78-22 \times$ Fundy & 35.3 & 28.2 & 33.0 & 32.2 & 31.0 & 33.4 \\
\hline 35 & $78-22 \times 77-10$ & 33.5 & 26.8 & 33.5 & 29.2 & 26.1 & 29.4 \\
\hline 36 & $79-12 \times$ Fundy & 27.0 & 23.3 & 27.3 & 23.5 & 22.7 & 25.5 \\
\hline 37 & 79-12 × Brun. & 29.7 & 23.8 & 27.7 & 24.5 & 23.6 & 26.7 \\
\hline 38 & $79-12 \times 416$ & 26.2 & 21.2 & 24.8 & 22.5 & 20.9 & 23.6 \\
\hline 39 & $79-12 \times 77-10$ & 33.8 & 22.8 & 28.2 & 23.7 & 23.7 & 27.7 \\
\hline 40 & $79-12 \times 80-05$ & 28.5 & 25.5 & 31.8 & 25.0 & 24.5 & 28.2 \\
\hline 41 & $79-12 \times 80-07$ & 29.7 & 23.7 & 29.3 & 27.8 & 25.6 & 27.3 \\
\hline 42 & $83-05 \times$ Fundy & 30.7 & 25.8 & 32.5 & 28.7 & 27.5 & 29.4 \\
\hline ANOI & F probability & $<0.001$ & $<0.001$ & $<0.001$ & $<0.001$ & $<0.001$ & $<0.001$ \\
\hline $\operatorname{LSD}(P$ & $0.05)$ & 4.4 & 3.1 & 4.5 & 2.9 & 4.1 & 2.5 \\
\hline Degre & of freedom & 200 & 201 & 201 & 82 & 82 & 198 \\
\hline Grand & ean of $42 \mathrm{KBFs}$ & 29.5 & 23.0 & 29.3 & 26.8 & 22.9 & 26.8 \\
\hline
\end{tabular}

${ }^{\mathrm{z}}$ Based on three blocks.

${ }^{y}$ Mean of 1992, 1994, 1996, 1998 from analysis of variance taking block and year effects into consideration.

This exceeds yields from commercial lowbush blueberry fields. The cross between Augusta and 451, which was highly productive in the study by Aalders and Hall (1975), was consistently below average in this trial, which indicates that genetic gains have been made in yield. Among all 42 $\mathrm{KBFs}$, the weight of 50 berries varied from 20.1 to $33.4 \mathrm{~g}$ ( 403 to $668 \mathrm{mg}$ per berry; Table $3)$; larger than lowbush blueberries from commercial fields, which are often 200 to $400 \mathrm{mg}$ (Hall, 1983; Jordan and Eaton, 1995). This demonstrates that selection for large berry size, a primary selection criterion, has been effective.

The degree of rhizome formation and, therefore, the spreading to fill the available land area, differed greatly among the KBFs as measured by the plot-fill rating ( 0 to 4 ) in the fifth growing season. KBFs producing fewer rhizomes (mean score less than 2) included KBF 14, 16, 19, 31, 32, and 35. The parents of these included tall, branched genotypes such as 'Brunswick', 73-9, and 73-22. Faster spreading KBFs (mean score greater than 3 ) included KBF-5, -10, -28, -36, -37, -38, -39, and -40 . These had either 416 or $79-12$ as one parent, indicating that these genotypes, chosen as parents for their ability to produce rhizomes, passed on this ability to many of their seedlings. The highest score was 3.8 recorded for $79-12 \times 416$.

The number of plants in an eight-plant plot that was markedly different from the norm was recorded in the fifth growing season. The overall mean was two atypical plants per plot and the range was 1.2 for KBF 2 to 2.7 for KBF 32 and 35. Variation among genotypes in this variate was not considered significant (data not shown). Generally, the atypical plants showed reduced vigor and yield.

Based on yields and fruit quality characteristics in the 1992 to 1998 harvests, KBF-7, $-10,-13$, and -42 were chosen for continued evaluation (Table 4). Over six harvest seasons, the large-fruited KBF-7 averaged 570 mg per berry and the medium-sized KBF 10 averaged $460 \mathrm{mg}$ (Table 4). Each of the four families has 'Fundy' as one parent, contributing firm, attractive, light blue fruit. The highest ratings for berry bloom and firmness were for KBF-42; however, its yield was not exceptional (Table 4). KBF-13 was productive and large-fruited; however, the harvested crop often contained many green, unripe berries. KBF-10 is the seedling family producing fruit of a size and appearance most similar to commercial lowbush blueberries. It produces numerous rhizomes in early years and may be suited to planting into bare spots in commercial fields. KBF-7, which has been named 'Novablue' (Clark and Finn, 2006), combines high yield, large fruit, and favor-

Table 4. Fruit yield, berry weight, and other characteristics of four selected Kentville blueberry families (KBFs).

\begin{tabular}{|c|c|c|c|c|c|c|c|c|}
\hline \multirow[b]{2}{*}{ Kentville blueberry family } & \multirow{2}{*}{$\begin{array}{c}\begin{array}{c}\text { Yield } \\
\text { (g/plot) }\end{array} \\
1992 \text { to } 2000\end{array}$} & \multirow{2}{*}{$\begin{array}{l}\text { Weight (g) } \\
\text { of } 50 \text { berries } \\
1992 \text { to } 2000\end{array}$} & \multicolumn{6}{|c|}{ Ratings $^{\mathrm{z}}$ of horticultural characteristics in 1994} \\
\hline & & & $\begin{array}{l}\text { No. atypical } \\
\text { plants }^{y}\end{array}$ & $\begin{array}{l}\text { Plot fill }^{x} \\
\text { (0 to } 4)\end{array}$ & $\begin{array}{l}\text { Bloom }^{\mathrm{w}} \\
(1 \text { to } 5)\end{array}$ & $\begin{array}{l}\text { Appearance }{ }^{\mathrm{w}} \\
\text { (1 to } 5)\end{array}$ & $\begin{array}{l}\text { Firmness }^{\mathrm{w}} \\
(1 \text { to } 5)\end{array}$ & $\begin{array}{l}\text { Flavor }^{\mathrm{w}} \\
(1 \text { to } 5)\end{array}$ \\
\hline 7 & 2,819 & 28.5 & 1.3 & 2.7 & 3.8 & 3.7 & 4.0 & 3.3 \\
\hline 13 & 2,745 & 28.0 & 1.5 & 2.8 & 3.8 & 3.3 & 3.8 & 3.1 \\
\hline 42 & 2,001 & 27.0 & 1.8 & 3.0 & 4.5 & 3.8 & 4.6 & 3.4 \\
\hline ANOVA $-F$ probability & 0.338 & $<0.001$ & 0.127 & $<0.001$ & $<0.001$ & $<0.001$ & $<0.001$ & $<0.001$ \\
\hline $\operatorname{LSD}(P=0.05)$ & $1,034.9$ & 2.05 & 0.88 & 0.74 & 0.50 & 0.54 & 0.53 & 0.54 \\
\hline
\end{tabular}

${ }^{2}$ The statistical analysis (F propability, least significant difference, and grand mean) for these characteristics is based on all $42 \mathrm{KBFs}$.

${ }^{y}$ The number of plants in a plot of eight plants, which were clearly different from the family phenotype.

${ }^{\mathrm{x}} \mathrm{A}$ rating of the amount of plant spreading by rhizome production on a scale of $0=$ plants dead to $4=$ excellent spreading.

${ }^{\mathrm{w}} \mathrm{A}$ rating of the waxy bloom, overall appearance of a tray of harvested fruit, firmness, and flavor on a scale of $1=$ worst to $5=$ best. 
able fruit characteristics (Table 4) and is considered the best suited to production for fresh berry sales.

\section{Conclusions}

The program to genetically improve the lowbush blueberry began at AAFC-Kentville in the 1960s by Ivan Hall and Lewis Aalders with the able assistance of Avard Brydon and led to the introduction of six clonally propagated cultivars, culminating in 'Fundy' (Hall et al., 1988). Although these cultivars were capable of producing high yields of large berries, interest remained in growing seedlings, although seedlings from open pollination are low-yielding (Hall, 1983) because seedlings are easier to establish in the field and plants should be less expensive. The two proposed uses of lowbush blueberry plants are for filling in bare spots in existing fields and for establishing new fields principally for fresh-market berries. KBF-10 is recommended for the former purpose and KBF-7 for the latter. The completion of this study brings the lowbush blueberry genetic enhancement research at AAFC-Kentville to a close.

\section{Literature Cited}

Aalders, L.E. and I.V. Hall. 1975. A study of variation in fruit yield and related characteristics in two diallels of the lowbush blueberry,
Vaccinium angustifolium Ait. Can. J. Genet. Cytol. 17:401-404.

Aalders, L.E., I.V. Hall, and A.C. Brydon. 1979 A comparison of fruit yields of lowbush blueberry clonal lines and related seedling progenies. Can. J. Plant Sci. 59:875877.

Aalders, L.E., I.V. Hall, and L.P. Jackson. 1972. Growth of lowbush blueberry seedlings as compared with clonal cuttings. Can. J. Plant Sci. 52:655-666.

Brierley, W.G. and W.H. Kenety. 1920. Blueberry culture in Minnesota: A report of progress. Proc. Amer. Soc. Hort. Sci. 17:243249.

Burgher, K.L., A.R. Jamieson, and X. Lu. 2002. Genetic relationships among lowbush blueberry genotypes as determined by random amplified polymorphic DNA analysis. J. Amer. Soc. Hort. Sci. 127:98-103.

Burgher-MacLellan, K.L. and K. MacKenzie. 2004. An overview of RAPD analysis to estimate genetic relationships in lowbush blueberry. Small Fruits Rev. 3:295-305.

Clark, J.R. and C.E. Finn. 2006. Register of new fruit and nut cultivars: List 43. HortScience 41:1101-1133.

Eaton, E.L. 1954. Horticulture. In: Progress report 1949-1953. Canada Department of Agriculture, Dominion Blueberry Sub-Station, Tower Hill, NB, Canada.

Hall, I.V. 1983. Genetic improvement of the lowbush blueberry, Vaccinium angustifolium. Can. J. Plant Sci. 63:1091-1092.

Hall, I.V., L.E. Aalders, N.L. Nickerson, and S.P. Vander Kloet. 1979. The biological flora of Canada. 1. Vaccinium angustifolium Ait., sweet lowbush blueberry. Can. Field-Naturalist 93 : 415-430.
Hall, I.V., A.R. Jamieson, and A.C. Brydon. 1988 Cumberland and Fundy lowbush blueberries. Can. J. Plant Sci. 68:553-555.

Hepler, P.R. and D.E. Yarborough. 1991. Natural variability in yield of lowbush blueberries. HortScience 26:245-246.

Jamieson, A.R. and N.L. Nickerson. 2003. Field performance of the lowbush blueberry propagated by seed, stem cuttings and micropropagation. Acta Hort. 626:423-428.

Johnston, S. 1935. Propagating low- and highbush blueberry plants by means of small side shoots. Proc. Amer. Soc. Hort. Sci. 33:372-375.

Jordan, W.C. and L.J. Eaton. 1995. A comparison of first and second cropping years of Nova Scotia blueberries (Vaccinium angustifolium Ait.). Can. J. Plant Sci. 75:703-707.

Kender, W.J. 1965. Some factors affecting the propagation of lowbush blueberries by softwood cuttings. Proc. Amer. Soc. Hort. Sci. 86:301-306.

Kender, W.J. 1966. Domestication of the lowbush blueberry, p. 147-149. In: Kender, W.J. and D.A. Abdalla (eds.). Proc. N. Amer. Blueberry Workers Conf., Maine Agr. Exp. Sta. Misc. Rep. 118.

Kender, W.J. 1967. On the domestication of the lowbush blueberry. Fruit Var. Hort. Dig. 21: 74-76.

Payne, R.W. (ed.). 2000. The guide to GenStat ${ }^{\circledR}$. Part 2. Statistics. VSN Intl. Ltd., Oxford, UK.

Smagula, J.M. and D.E. Yarborough. 1990. Changes in the lowbush blueberry industry. Fruit Var. J. 44:72-77.

Wood, G.W. 2004. The wild blueberry industryPast. Small Fruits Rev. 3:11-18.

Yarborough, D.E. 2004. Factors contributing to the increase in productivity in the wild blueberry industry. Small Fruits Rev. 3:33-43. 